\title{
Intermittent upwelling and subsidized growth of the scleractinian coral Madracis mirabilis on the deep fore-reef slope of Discovery Bay, Jamaica
}

\author{
James J. Leichter ${ }^{1, *}$, Salvatore J. Genovese ${ }^{2}$ \\ ${ }^{1}$ Scripps Institution of Oceanography - 0227, University of California at San Diego, 9500 Gilman Drive, La Jolla, \\ California 92093, USA \\ ${ }^{2}$ Three Seas Program, Marine Science Center, Northeastern University, Nahant, Massachusetts 01908, USA
}

\begin{abstract}
A 1 yr study was conducted across a $45 \mathrm{~m}$ depth gradient on the north shore of Jamaica to explore the hypothesis that depth-specific variability associated with thermocline oscillations effects growth rates of the scleractinian coral Madracis mirabilis. Multiple periods of high-frequency temperature variability were detected at 30 to $55 \mathrm{~m}$ depth, indicative of vertical transport of subthermocline water onto the reef slope at semidiurnal and shorter intervals. Cooling, expressed as cumulative degree-days below the depth-averaged daily temperature increased from $1.6^{\circ} \mathrm{C} \mathrm{d}$ at $10 \mathrm{~m}$ to $50^{\circ} \mathrm{C}$ d at 45 and $55 \mathrm{~m}$ depth. The sum of the daily temperature variance increased almost 3-fold from 3.7 to $9.9^{\circ} \mathrm{C}^{2}$ from 10 to $55 \mathrm{~m}$. Coral growth rates showed a bimodal distribution as a function of depth, with fastest growth (3.86 to $4.12 \mathrm{~g} \mathrm{yr}^{-1}$ ) at 10 and $30 \mathrm{~m}$, reduced growth (2.46 to $3.21 \mathrm{~g} \mathrm{yr}^{-1}$ ) at 20 and $45 \mathrm{~m}$, and slowest growth $\left(0.97 \mathrm{~g} \mathrm{yr}^{-1}\right)$ at $55 \mathrm{~m}$. To assess possible differences among sites differing with respect to the intensity of internal-wave forcing, growth rates of $M$. mirabilis were compared at 20 and $30 \mathrm{~m}$ depth in Jamaica with previous results from the Florida Keys. Overall growth rates were greater in Florida than in Jamaica, corresponding to greater internal-wave activity in Florida, and a similar effect of enhanced growth at $30 \mathrm{~m}$ was observed at both sites. Vertical oscillations of the thermocline are a widespread phenomenon, and may contribute to patterns of coral growth in a variety of deep reef environments.
\end{abstract}

KEY WORDS: Coral growth $\cdot$ Internal waves $\cdot$ Deep reefs $\cdot$ Madracis mirabilis

Resale or republication not permitted without written consent of the publisher

\section{INTRODUCTION}

The zonation of coral morphologies, species distributions and reef structures across depth gradients represents one of the most widely observed, general patterns on coral reefs worldwide (Done 1983, Veron 1995). The 2 most prominent physical factors that drive these patterns across depth are light availability and water motion induced by wind and surface waves (Jokiel 1978, Falkowski et al. 1990, Massel \& Done 1993, Yentsch et al. 2002). The strong decrease in both the magnitude and variability of light and water motion with increasing depth, may lead to a view of deep reef habitats (e.g. depth $>30 \mathrm{~m}$ ) as stable environments where physical conditions are more predictable than those at shallower depths. However, not all physical factors vary with depth in the same manner as light and wave exposure, and the interaction of multiple physical gradients across depth can lead to complex patterns of resource availability across space and time on coral reefs.

On reefs subject to persistent internal wave activity, the variability in temperature, dissolved nutrients and suspended particle concentrations may be highly episodic and may increase significantly from shallow reef crests to deep slopes (Leichter et al. 1996). For example, on the outer slope of the Great Barrier Reef and reef slopes along the Florida Keys, strong internal tidal activity along the thermocline seaward of reefs produces rapid fluctuations in temperature measured on the reef slope and episodic input of subsurface nutrients and suspended particles to deep reef environments (Wolanski \& Pickard 1983, Wolanski 1994, Leichter et al. 1996, 1998, 2003). For the Florida Keys, Leichter et al. (2003) pre- 
sented evidence for increasing utilization of subthermocline nutrients by a benthic macroalga with increasing exposure to internal wave pulses at increasing depth. In an earlier study at the same site, Leichter et al. (1998) showed a bimodal distribution of $M$. mirabilis growth rates as a function of depth from 15 to $30 \mathrm{~m}$. High growth rates at $30 \mathrm{~m}$ were interpreted as a reflection of enhanced particle availability due to the persistent impact of internal bores deep on the reef slope.

Calcification and growth rates of scleractinian corals are strongly influenced by light availability (Barnes \& Chalker 1990, Falkowski et al. 1990), temperature (Yonge 1940, Hoegh-Guldberg \& Smith 1989, Jokiel \& Coles 1990, Coles \& Fadlallah 1991), and complex interactions of light and temperature with other physical factors such as the concentration of $\mathrm{CO}_{2}$ (Kleypas et al. 1999). In addition, because most corals function as both autotrophs via photosynthesis of their symbiotic zooxthanellae and as heterotrophs via suspension feeding by the coral polyps, calcification and growth can be enhanced by the availability of zooplankton (Porter 1974, Sebens et al. 1996, 1998), and other particles, including microzooplankton (Ferrier-Pages et al. 1998), bacteria (Bak et al. 1998) and suspended particulate matter and sediment (Stafford-Smith \& Ormond 1992, Anthony 1999, 2000, Anthony \& Fabricius 2000). The relative importance of suspension feeding has been shown to shift with light availability and particle flux and to vary among species (Anthony \& Fabricius 2000, Anthony \& Hoegh-Guldberg 2003).

The Caribbean finger coral Madracis mirabilis (Duchassaing \& Michelotti, 1860) (family Pocilloporidae) has been shown to acquire significant nutrition from suspension feeding (Sebens et al. 1996, 1997, 1998). Because of its relative robustness to experimental handling, branching morphology with rapid growth rates, and typically high abundance on Caribbean reefs, $M$. mirabilis has been a coral of choice for numerous physiological and ecological investigations (e.g. Bruno \& Edmunds 1997, 1998, Sebens et al. 1997). Species within the genus Madracis are thought to represent a species complex and exist across a wide rage of depths from shallow water to at least 60 m (Vermeij \& Bak 2003, Vermeij et al. 2004). In Jamaica, M. mirabilis has been shown to exhibit significant phenotypic plasticity and environmentally induced variability in corallite morphology, which is thought to contribute to its broad ecological range (Bruno \& Edmunds 1997). At whole colony scales, increased spacing among $M$. mirabilis branches has been shown to be positively correlated with colony respiration rates at slow flow-speeds (Bruno \& Edmunds 1998). The morphological plasticity and relatively rapid growth rates give $M$. mirabilis strong potential to exhibit location specific growth responses to environmental microhabitats (Bruno \& Edmunds 1997).
This study was designed to assess the impact of internal waves on a coral reef slope along the north coast of Jamaica, and to measure depth-specific patterns in the growth of Madracis mirabilis across a depth range from 10 to $55 \mathrm{~m}$. Compared with sites of previous internal wave research in Florida, the reef slope in Jamaica is significantly steeper, and the hydrographic regime is likely to differ due to latitudinal differences in stratification and the absence in Jamaica of a major alongshore current comparable to the Florida Current, which produces strong alongshore flows and variability in the Florida Keys (Leichter et al. 1996, Leichter 2003). The general approach was to measure near-bottom temperature at high frequency at multiple depths in conjunction with a transplant experiment with branch tips of $M$. mirabilis collected from a common source location and transplanted to 5 depths across the fore-reef slope. Growth rates from Jamaica were compared with prior results from Florida to assess differences among sites which might be related to variation in internal wave forcing

\section{MATERIALS AND METHODS}

This study was conducted at Discovery Bay, Jamaica $\left(18^{\circ} 28^{\prime} 00^{\prime \prime}\right.$ N, $77^{\circ} 24^{\prime} 30^{\prime \prime}$ W, Fig. 1) from January 1999 to January 2000. Benthic temperature recorders and coral transplant experiments were deployed at depths of $10,20,30,45$ and $55 \mathrm{~m}$ along a transect on the forereef slope near the University of the West Indies Discovery Bay Marine Laboratory. Individual temperature recorders (Onset Computer, temperature resolution $0.2^{\circ} \mathrm{C}$ ) were placed in pressure housings with the temperature sensing thermistors in small, protruding, stainless steel probes giving a thermal response time of approximately $20 \mathrm{~s}$ in water. The instruments were fixed $1 \mathrm{~m}$ above the reef surface at each study

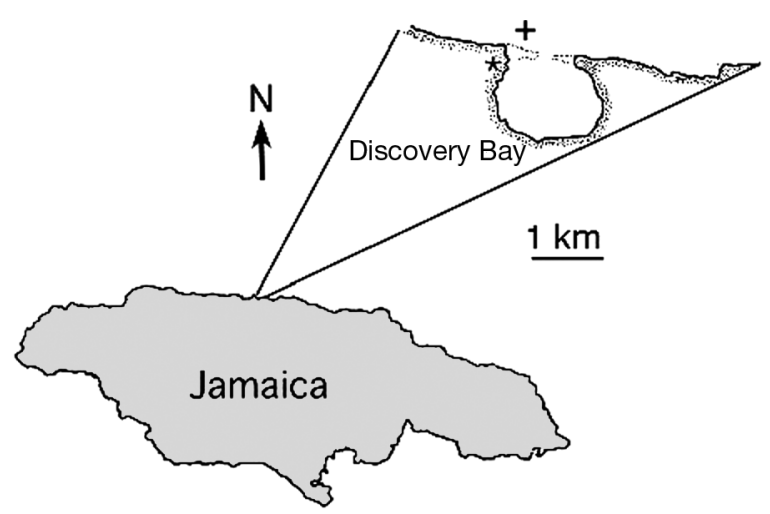

Fig. 1. Location of study site at Discovery Bay, north coast of Jamaica. *: Discovery Bay Marine Laboratory; +: fore-reef study site at Long-term study (LTS) 
depth, sampling at $2 \mathrm{~Hz}$ and recording average values at 16 min intervals.

The recorded temperature time series were plotted and power spectra were calculated and examined for evidence of high-frequency variability across depths. Power spectra are expressed in units corresponding to the temperature variance $\left({ }^{\circ} \mathrm{C}^{2}\right)$ as a function of frequency (cycles $\mathrm{d}^{-1}$ ). Daily values of the temperature mean, minimum, maximum and variance were calculated for each depth as well as the overall mean, minimum, maximum and cumulative total variance (the sum of within-day variance across all days). A depth averaged daily mean temperature was calculated as the average of the daily running mean across all sampling depths. Depth specific temperature deviations were calculated by subtracting the depth averaged temperature from the continuous record from each depth. The cumulative degree-days of cool and warm deviation from the depth averaged temperature were calculated for each depth by multiplying the negative (cool) and positive (warm) deviations by the sampling interval in days $(0.0111 \mathrm{~d})$ and taking the sum of the resulting values. Because the logger at $10 \mathrm{~m}$ depth failed after $262 \mathrm{~d}$ the cumulative degree-days at each depth was compared only for the period when data were available from all depths.

Light availability was not measured during the study because of the logistic difficulty of preventing fouling of recording lightmeters in a subtidal location for long periods. However, an idealized curve for the attenuation of light with depth was calculated using Beers' law (Jerlov 1966) and an extinction coefficient of $k=-0.063$ $\mathrm{m}^{-1}$ previously measured for downwelling light in the Caribbean (at Curaçao) (Vermeij \& Bak 2002). This extinction coefficient is within the range typically expected for relatively clear Caribbean waters (M. Vermeij pers. comm.). The purpose of calculating this light attenuation curve was simply to investigate a realistic expectation for the percentage of surface irradiance likely to be available at depth rather than to suggest specific irradiance levels at the study site.

Growth rates of Madracis mirabilis were investigated in a 12 mo transplant experiment. Branch tips were collected from a range of colonies at a common site at $15 \mathrm{~m}$ depth on the fore-reef slope and held in a laboratory flow-through seawater system for a maximum of 1 to $2 \mathrm{~d}$ for measurements prior to transplantation back to the reef slope. Branches were briefly removed from water and weighed wet, then attached to individual, numbered holders using underwater epoxy (Z-spar ${ }^{\mathrm{TM}}$ splash zone compound) and reweighed. The wet weight of each branch tip and that of the branch tip with its transplant holder and epoxy was recorded, and branch tips were randomly assigned to depth treatments of 10, 20, 30,45 or $55 \mathrm{~m}$. The initial sizes of the branch tips were approximately 3 to $8 \mathrm{~cm}$ in length, ranging in mass from 1.491 to $9.607 \mathrm{~g}$, with a mean of $4.075 \mathrm{~g}$. An equivalent range of initial sizes was assigned to each treatment depth. We transplanted 40 individual branch tips to each depth (200 branch tips total). Colony of origin was noted, but this information was not used in the subsequent analysis because it was not possible to collect an equal and sufficient number of branches from each colony to have all colonies represented at all depths. The branch tips in individual holders were returned to the fore-reef slope and individually attached to non-living coral substrate within 1 to $5 \mathrm{~m}$ of the temperature recorder at each depth. The experiment was initiated between 10 and 15 January 1999 and terminated between 8 and 15 January 2000 when the corals were retrieved and returned to the laboratory. Any epiphytes growing on the transplant holders were removed, and the wet weights of all corals that were alive at the end of the experiment were measured with the holders. The corals and holders were then dried at $60^{\circ} \mathrm{C}$ for $24 \mathrm{~h}$ and reweighed. The constant weight of each holder was subtracted to yield a change in wet weight of the corals. Linear regression between final wet and dry weights of the corals $\left(r^{2}=0.985\right)$, was used to back-calculate coral initial dry weight from the initial wet weight data. Growth rate $\left(\mathrm{g} \mathrm{yr}^{-1}\right)$ was calculated as change in mass over the 1 yr duration of the experiment.

The effect of treatment depth on Madracis mirabilis growth rate was analyzed using analysis of covariance (ANCOVA), with depth as the treatment factor and initial coral weight as the covariate. ANCOVA and posthoc, pairwise comparisons of the adjusted group means via a Tukey HSD-test were calculated in the JMP statistical software package (SAS Institute). Both the response variable and covariate were checked for homogeneity of variances with an F-test. Growth data were log-transformed to help stabilize the variance among depth treatments. In cases where complete homogeneity of variance could not be achieved, the critical probability level was adjusted downward accordingly (Day \& Quinn 1989, Underwood 1997).

Results from the growth experiment in Jamaica were compared to previous results for Madracis mirabilis growth from an experiment conducted in 1995 at Conch Reef, Florida Keys, USA (Leichter et al. 1998), using ANCOVA, with location and depth as treatment factors and initial dry weight as the covariate. Because the Florida study was conducted at 15, 20 and $30 \mathrm{~m}$, while the Jamaica study was conducted at 10, 20, 30, 45 and $55 \mathrm{~m}$, only data from 20 and $30 \mathrm{~m}$ at both sites were compared. Growth data were normalized to yearly rates $\left(\mathrm{g} \mathrm{yr}^{-1}\right)$, because of a small difference in length between experiments (Jamaica $=12 \mathrm{mo}$; Florida Keys $=15.5 \mathrm{mo}$ ). Data were log-transformed to stabilize the variance of the growth data and the covariate initial weight. 


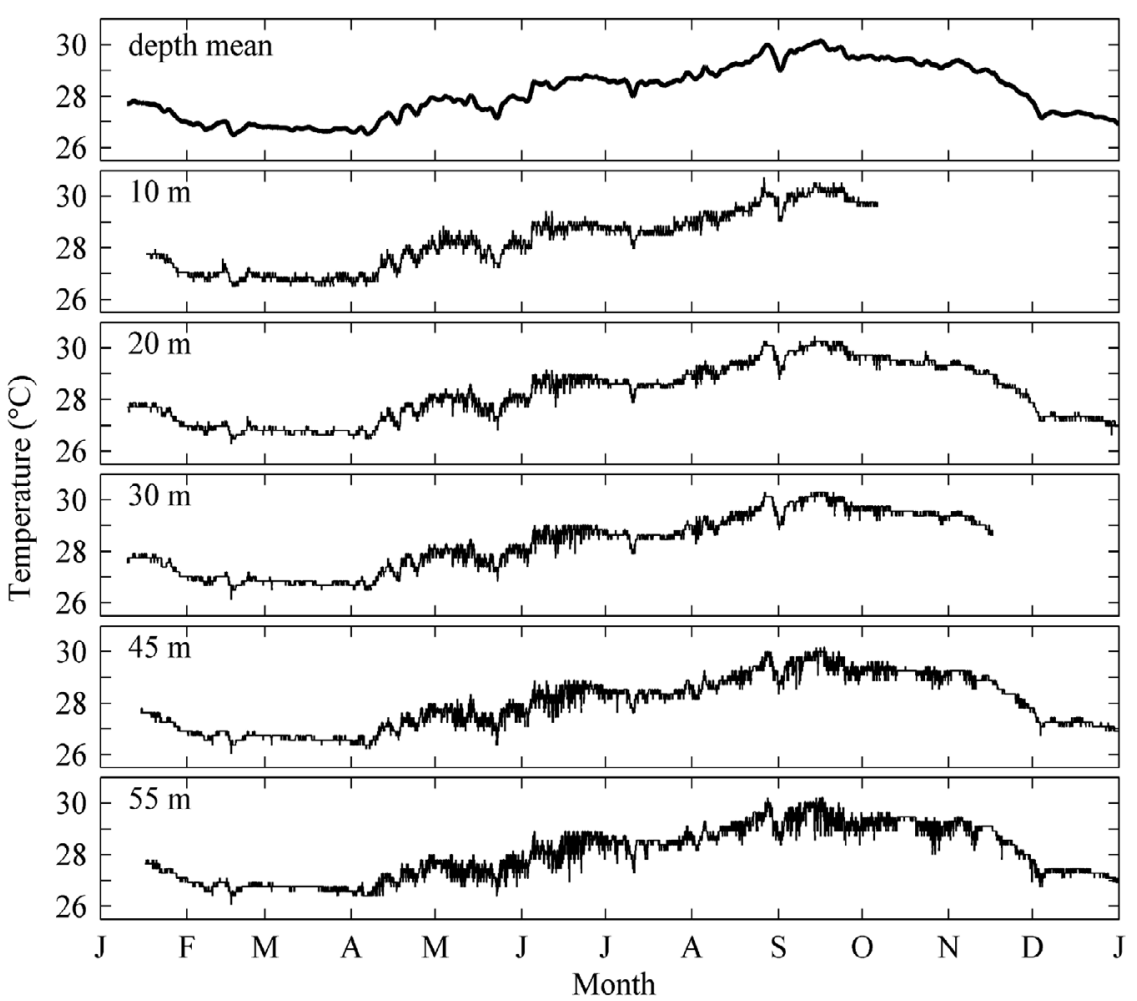

Fig. 2. Depth average of daily running mean temperature at 10 to $55 \mathrm{~m}$ (top panel) and the continuous temperature record at each study depth for period January 1999 to January 2000

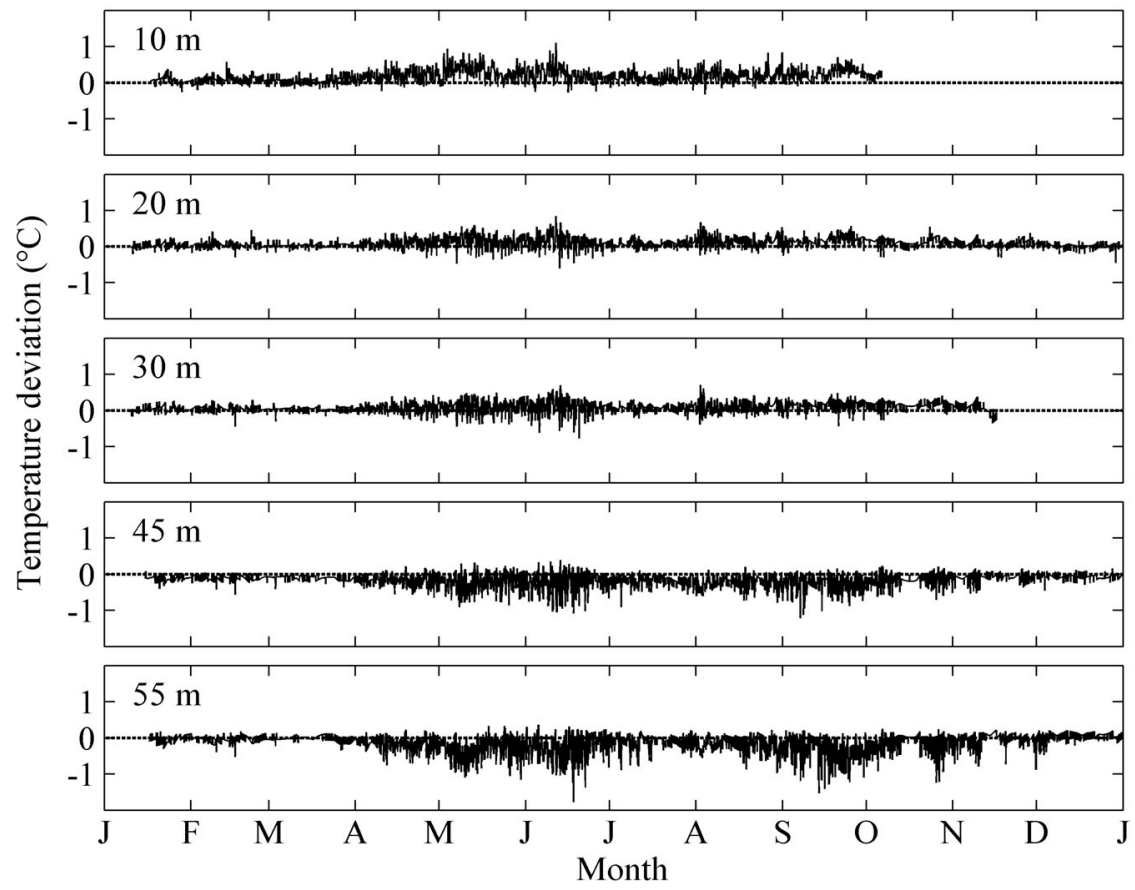

Fig. 3. Deviation at 10, 20, 30, 45, and $55 \mathrm{~m}$ depth from depth-averaged daily mean temperature (shown in Fig. 2). Individual data points recorded at 16 min sampling intervals. Dotted horizontal line indicates zero deviation

\section{RESULTS}

The temperature at each depth as well as the depth averaged temperature time series show relatively small seasonal variability from winter to summer at all depths (Fig. 2) with a mean, minimum and maximum of 28.1, 26.5, and $30.1^{\circ} \mathrm{C}$ respectively. Periods of high-frequency deviation from the seasonal signal were evident at 30, 45 and $55 \mathrm{~m}$ depth (Fig. 3). The highfrequency variance increased with increasing depth and occurred primarily during the summer (May through September). The variability at 30, 45 and $55 \mathrm{~m}$ was primarily composed of episodes of rapid cooling relative to the depth-averaged daily mean temperature. Maximum cooling and the associated variability occurred in June and September. Fig. 4 shows the temperature time series during one of the periods of increased variability on 10 to 24 June. The power spectrum for the period 1 May to 15 July is shown in

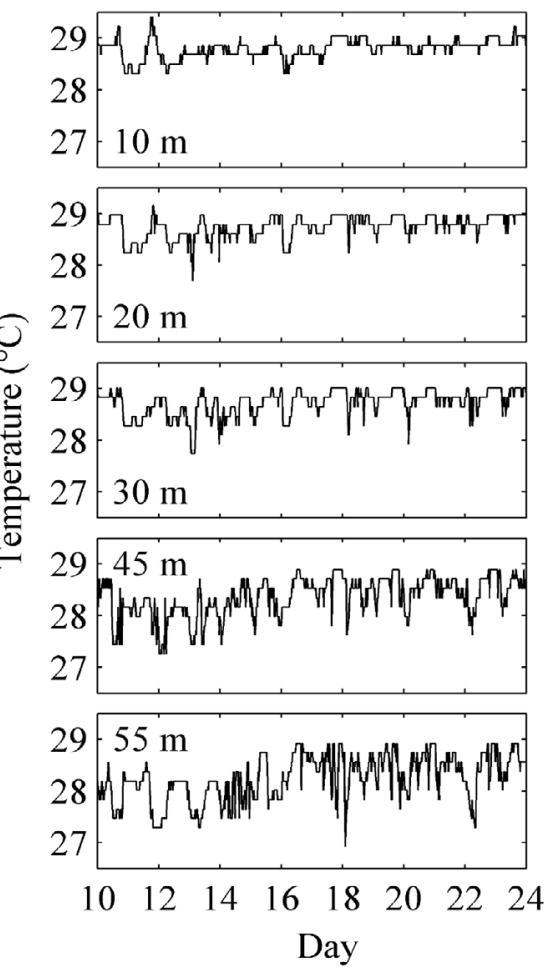

Fig. 4. $14 \mathrm{~d}$ segment of 16 min raw temperature record at 10 to $55 \mathrm{~m}$ depth, 10 to 24 June 1999 illustrating high-frequency cooling events at the deeper sites 


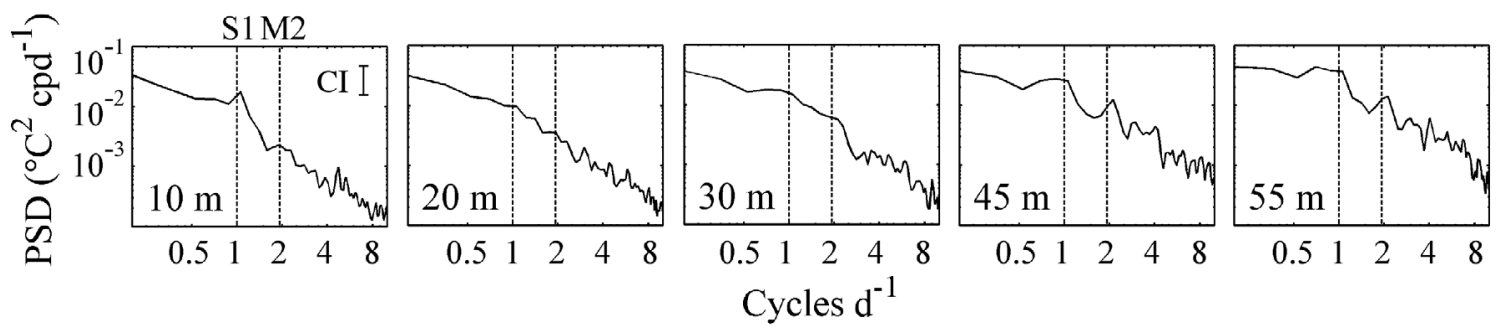

Fig. 5. Power spectral density, PSD $\left({ }^{\circ} \mathrm{C}^{2}\right.$ per cycle-per-day) as a function of frequency at 10 to $55 \mathrm{~m}$ depth for period $1 \mathrm{May}$ to 15 July 1999. Spectra and $95 \%$ confidence intervals (CI) calculated on detrended 16 min interval data by Welch's averaged periodogram method with length of fast Fourier transform $=512$ and $\mathrm{df}=26$. Dashed vertical lines labeled S1 and M2 indicate solar diurnal and lunar semi-diurnal tidal frequencies respectively. Error bar in top panel indicates $95 \%$ confidence interval for all spectra

Fig. 5. Temperature variability was distributed across a range of frequencies from approximately 0.5 to 8 cycles $\mathrm{d}^{-1}$ and increased with increasing depth. A peak in variance at approximately 1.8 to 2.2 cycles $\mathrm{d}^{-1}$ was evident at 45 and $55 \mathrm{~m}$ depth, suggesting variability at these depths driven by semidiurnal internal waves.

Summaries of the temperature patterns as a function of depth are shown in Fig. 6. While the mean, minimum and maximum across the entire year were quite consistent across depths, both the maximum withinday temperature range and the sum of the daily variance increased at 45 and $55 \mathrm{~m}$ relative to the values at shallower depths. The cumulative warm degree-days above the depth averaged running daily mean temperature were $47.4,30.3,26.7,1.2$ and $3.5^{\circ} \mathrm{C} \mathrm{d}^{-1}$ at 10,20 , 30,45 and $55 \mathrm{~m}$ respectively, while the cumulative cool degree-days below the depth-averaged mean were $1.6,3.0,4.6,50.0$ and $50.3^{\circ} \mathrm{C} \mathrm{d}^{-1}$. These patterns reinforce the pattern in Fig. 3 of variability primarily associated with warming above the depth-averaged mean at the shallow sites and with cooling at the deeper sites. At the $30 \mathrm{~m}$ site, the variability was comprised of both warming and cooling, but a lesser extent of cooling than that at 45 and $55 \mathrm{~m}$.

ANCOVA results for Madracis mirabilis growth rates revealed a significant effect for the treatment factor depth $(p<0.001$, Table 1$)$. The mean growth rates adjusted for the effect of initial weight and backtransformed from log data to units of $\mathrm{g} \mathrm{yr}^{-1}$ are shown in Fig. 7. Positive growth rates were measured at all depths. A bimodal pattern of growth rates as a function of depth was evident, with fastest mean growth at $30 \mathrm{~m}$ $\left(4.12 \pm 0.27 \mathrm{~g} \mathrm{yr}^{-1}\right)$ and $10 \mathrm{~m}\left(3.86 \pm 0.34 \mathrm{~g} \mathrm{yr}^{-1}\right)$, followed by $45 \mathrm{~m}\left(3.21 \pm 0.20 \mathrm{~g} \mathrm{yr}^{-1}\right), 20 \mathrm{~m}(2.46 \pm 0.19 \mathrm{~g}$ $\left.\mathrm{yr}^{-1}\right)$ and $55 \mathrm{~m}\left(0.97 \pm 0.06 \mathrm{~g} \mathrm{yr}^{-1}\right)$ (Fig. 7). Pairwise comparisons showed that the growth rates at 10 and $30 \mathrm{~m}$ were significantly greater than at 20 and $55 \mathrm{~m}$, and that growth at $30 \mathrm{~m}$ was significantly faster than at $45 \mathrm{~m}$. Growth at 20 and $45 \mathrm{~m}$ were not significantly different, while growth rate at $55 \mathrm{~m}$ was significantly slower than at all other depths. The modeled exponen-

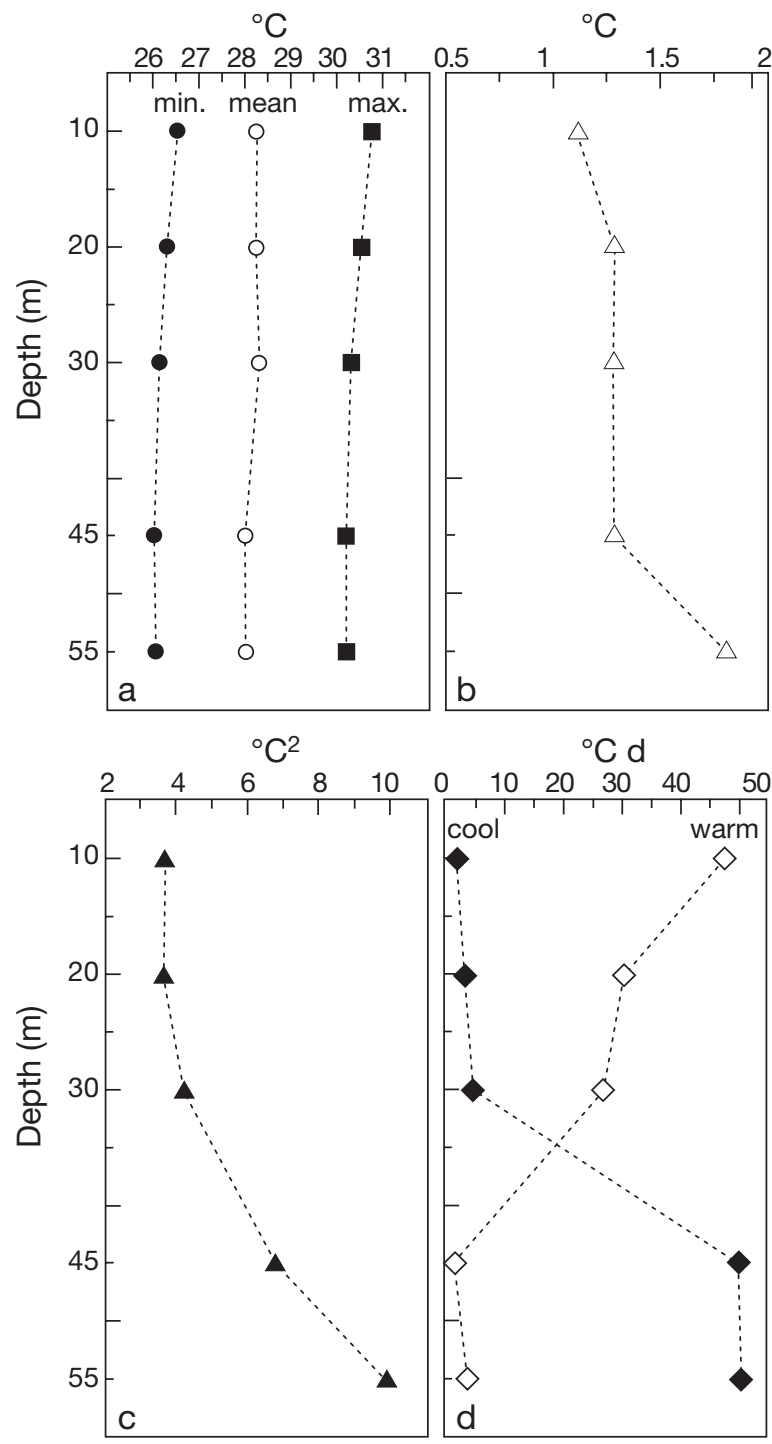

Fig. 6. Temperature summary statistics for period January 1999 to January 2000 as a function of depth from 10 to $55 \mathrm{~m}$. (a) Overall yearly minimum, mean, and maximum temperatures, (b) maximum daily temperature range, (c) cumulative total of the daily variance, (d) cumulative degree-days above (warm) and below (cool) depth-averaged daily running mean temperature (shown in Fig. 2) 
Table 1. Madracis mirabilis. ANCOVA results for growth (logtransformed) at Discovery Bay, Jamaica

\begin{tabular}{lrrrc|}
\hline Treatment & df & MS & $F$ & $\mathrm{p}$ \\
\hline Initial wt & 1 & 1.004 & 37.232 & $<0.0001$ \\
Depth & 4 & 1.634 & 60.578 & $<0.0001$ \\
Depth $\times$ Initial wt & 4 & 0.065 & 2.402 & 0.053 \\
Error & 138 & 0.027 & & \\
& & & \\
Tukey HSD, significantly different, pairwise comparisons: \\
$10 \mathrm{~m}>20 \mathrm{~m}, 10 \mathrm{~m}>55 \mathrm{~m}$ \\
$20 \mathrm{~m}>55 \mathrm{~m}$, \\
$30 \mathrm{~m}>20 \mathrm{~m}, 30 \mathrm{~m}>55 \mathrm{~m}$ \\
$45 \mathrm{~m}>55 \mathrm{~m}$
\end{tabular}

tial decrease in light with increasing depth is also shown in Fig. 7 (dashed line). The irradiance at $10 \mathrm{~m}$ was approximately $60 \%$ of the surface level and dropped to $15 \%$ at $30 \mathrm{~m}$ and to $<5 \%$ at $55 \mathrm{~m}$.

Comparison of Madracis mirabilis growth rates at 20 and $30 \mathrm{~m}$ in Jamaica with previous results from the Florida Keys revealed significant effects of location

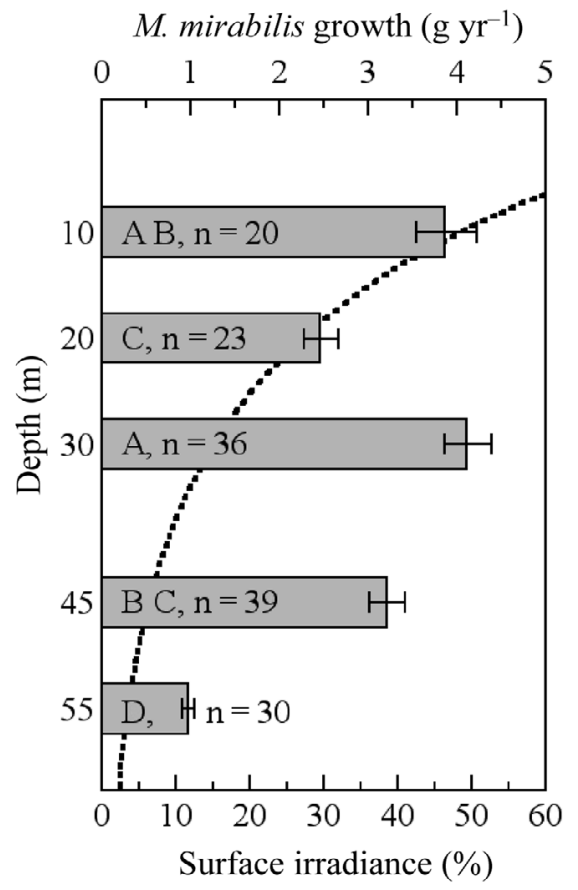

Fig. 7. Madracis mirabilis. Growth rates of branch tips collected at $15 \mathrm{~m}$ depth and transplanted to $10,20,30,45$, and $55 \mathrm{~m}$ depth. Bars: least-squares means adjusted for significant effect of initial branch-tip mass (ANCOVA); error bars: $\pm 1 \mathrm{SE}$ of mean. Depth groups not connected by same letters (A to D) are significantly different (Tukey HSD posthoc comparison). Sample sizes for each depth show number of surviving individuals out of $n=40$ transplanted. Dotted line shows modeled light availability at depth as a percentage of surface irradiance for extinction coefficient $k=-0.063 \mathrm{~m}^{-1}$ (line included to illustrate decrease in coral growth with depth that would be expected were growth simply related to light availability)
( $p=0.015)$ and depth $(p<0.001)$ (Table 2). Mean growth rates were higher in the Florida Keys than in Jamaica at both depths, and greater at 30 than at $20 \mathrm{~m}$ depth in both studies (Fig. 8). Clear differences in temperature were evident among sites (Table 3). The daily mean and the annual daily minimum were lower in Florida than in Jamaica, while the annual daily maximum was higher. The total daily variance was approximately 10-fold larger at the Florida Keys site than in Jamaica.

\section{DISCUSSION}

\section{Internal wave impacts}

The increasing temperature variance with depth across the reef slope and the rapid cooling at 30 to $55 \mathrm{~m}$ reflect the impingement of cool water masses transported onto the reef slope from deeper depths. The concentration of temperature variance at semidiurnal frequencies is indicative of internal wave activity within a thermally stratified water column. This suggests that internal waves are causing vertical oscillations of the thermocline seaward of the reef, especially in summer. Although the early and extensive ecological studies of the reefs at Discovery Bay have played a central role in the development of ecological understanding of Caribbean coral reefs (e.g. Goreau 1959, Lang 1973, Hughes \& Jackson 1985), this study represents, to our knowledge, the first evidence for internal wave impacts on the deep reef slopes in Jamaica. The regions of the reef

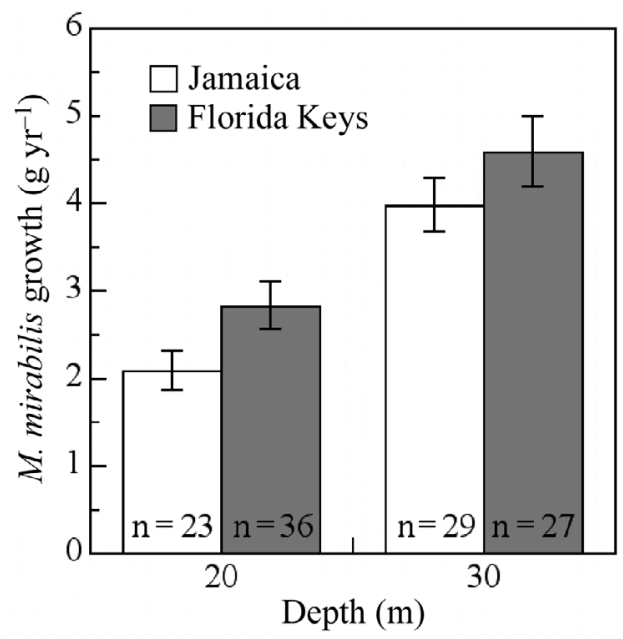

Fig. 8. Madracis mirabilis. Growth rates of branch tips transplanted to 20 and $30 \mathrm{~m}$ in Jamaica and in the Florida Keys (latter data from Leichter et al. 1998). Bars: least-squares means adjusted for significant effect of initial branch tip mass (ANCOVA); error bars: \pm 1 SE of mean. ANCOVA revealed significant effects of both depth $(30 \mathrm{~m}>20 \mathrm{~m})$ and location (Florida Keys > Jamaica) (Table 3) 
Table 2. Madracis mirabilis. ANCOVA results for growth (log-transformed) at 20 and $30 \mathrm{~m}$ depth at Discovery Bay, Jamaica, and Conch Reef, Florida Keys (latter data from Leichter et al. 1998)

\begin{tabular}{|lcccc|}
\hline Treatment & df & MS & $F$ & $\mathrm{p}$ \\
\hline Initial wt & 1 & 1.108 & 28.515 & $<0.0001$ \\
Location & 1 & 0.239 & 6.145 & 0.015 \\
Depth & 1 & 1.459 & 37.566 & $<0.0001$ \\
Location $\times$ Depth & 1 & 0.032 & 0.833 & 0.364 \\
Depth $\times$ Initial wt & 1 & 0.350 & 9.015 & 0.0033 \\
Location $\times$ Initial wt & 1 & 0.0002 & 0.007 & 0.933 \\
Depth $\times$ Location $\times$ & 1 & 0.0002 & 0.007 & 0.933 \\
Initial wt & & & & \\
Error & 107 & 0.0388 & & \\
\hline
\end{tabular}

slope at $30 \mathrm{~m}$ and deeper appear to be exposed to thermal regimes that differ significantly from those in shallower water, and this is likely to contribute to differences in ecological processes among deep and shallow reef environments (Bak et al. 2005). Interactions between incident internal waves and the reef spur and groove morphology are likely to produce physical heterogeneity within as well as across depths (Leichter et al. 2005).

While the present data for Jamaica show only the variation in temperature, it is likely that the movement of cool, subsurface waters onto the reef slope is accompanied by elevated fluxes of materials associated with the thermocline. On coral reefs in other locations, forcing by internal waves is associated with intermittent fluxes of dissolved nutrients and suspended particles (Wolanski \& Pickard 1983, Wolanski 1994, Leichter et al. 1998, 2003). This occurs because the temperature and density stratification at the thermocline corresponds to a zone separating warm, oligotrophic surface waters from deeper water with higher nutrient concentrations. In a wide variety of both tropical and temperate marine habitats, the strong density stratification at the thermocline is associated with layers of elevated phytoplankton and zooplankton concentrations (Mann \& Lazier 1996). For example, in summer, the water column seaward of the Florida Keys is characterized by a sharply-defined subsurface chlorophyll maximum layer at the thermocline and significantly elevated concentrations of dissolved nutrients below the thermocline relative to surface waters (Leichter et al. 2003). Near bottom transport and turbulence associated with breaking internal waves and internal bores have also been shown to affect sediment resuspension and transport in temperate systems and along the margin of continental shelves (Cacchione \& Drake 1986, Johnson et al. 2001). The magnitude of internal wave forcing in Jamaica appears to be smaller than that observed along the Florida Keys reef tract (Leichter et al. 1996,
Table 3. Daily mean, minimum and maximum temperature, and sum of daily temperature variance for Januray 1999 to January 2000 at Discovery Bay, Jamaica and for 1999 at Conch Reef, Florida Keys

\begin{tabular}{|lcccc|}
\hline $\begin{array}{l}\text { Depth } \\
(\mathrm{m})\end{array}$ & $\begin{array}{c}\text { Mean } \\
\left({ }^{\circ} \mathrm{C}\right)\end{array}$ & $\begin{array}{c}\text { Max. } \\
\left({ }^{\circ} \mathrm{C}\right)\end{array}$ & $\begin{array}{c}\text { Min. } \\
\left({ }^{\circ} \mathrm{C}\right)\end{array}$ & $\begin{array}{c}\text { Total daily } \\
\text { variance }\left({ }^{\circ} \mathrm{C}^{2}\right)\end{array}$ \\
\hline Discovery Bay & & & & \\
10 & 28.2 & 30.3 & 26.6 & 3.3 \\
20 & 28.2 & 30.3 & 26.5 & 3.5 \\
30 & 28.2 & 30.3 & 26.5 & 4.0 \\
45 & 28.0 & 30.0 & 26.4 & 6.6 \\
55 & 28.0 & 29.9 & 26.4 & 9.9 \\
Conch Reef & & & & \\
10 & 26.7 & 30.8 & 23.0 & 20.4 \\
20 & 26.7 & 30.6 & 23.0 & 29.7 \\
30 & 26.4 & 30.3 & 22.8 & 82.8 \\
\hline
\end{tabular}

1998) or at other sites in the Caribbean (J. Leichter \& B. Helmuth unpubl. data). Among-site comparisons can be a valuable approach to studying the ecological role of the high frequency forcing associated with internal waves on coral reefs in general.

\section{Coral growth rates}

The bimodal pattern of Madracis mirabilis growth as a function of depth suggests the existence of multiple gradients of resource availability with depth, and supports the general hypothesis that intermittent upwelling may serve to subsidize coral growth in deep reef environments where light availability is limited. However, as discussed above, the fluxes of suspended particles and dissolved nutrients potentially associated with internal wave impacts have yet to be measured at this site. The regimes of light, temperature and particle delivery are likely to be complex in this environment and their effects on coral growth rates are likely to interact in significant ways (Anthony \& Fabricius 2000, Anthony \& Hoegh-Guldberg 2003). In the southern Caribbean, coral communities in deep reef environments (depth $>25$ to $30 \mathrm{~m}$ ) experience a high degree of temperature variability suggestive of strong internal wave activity, and have not shown the marked decline in coral cover over the past $30 \mathrm{yr}$ that has been observed at shallower depths (Bak et al. 2006). Clearly, further investigation including detailed measurements of the vertical distribution of particles and nutrients in the offshore water column and the fluxes close to the reef surface are necessary to understand the mechanisms driving variation in coral growth as a function of depth on the reef slope at Discovery Bay and elsewhere.

The bimodal pattern of Madracis mirabilis growth measured here does not follow a simple pattern corresponding to light availability and depth. Rather, the 
results suggest that a complex set of processes can influence resource availability across depths. While light may be a central component of coral growth (Yentsch et al. 2002), previous work with a range of species of Madracis in the Caribbean has shown a wide tolerance of light environments (Vermeij \& Bak 2002) across this genus/species complex. In the present study, we measured positive growth rates even at the deepest site at $55 \mathrm{~m}$. M. mirabilis is likely to gain a significant component of its energy from heterotrophic particle capture (Sebens et al. 1997, Vermeij \& Bak 2002) and growth appears to be significantly enhanced by variability associated with internal waves and internal bores (Leichter et al. 1998). The bimodal pattern of M. mirabilis growth as a function of depth measured here is similar to a pattern shown previously in the Florida Keys (Leichter et al. 1998), but the overall growth rates are higher in Florida than in Jamaica. The decrease in mean growth rate at $20 \mathrm{~m}$ is consistent with the pattern observed previously in Florida.

The bimodal pattern of Madracis mirabilis growth appears to be a robust result observed at multiple sites where forcing associated with internal waves is present. However, neither the present study nor that of Leichter et al. (1998) have conclusively determined the causes of this pattern. A working hypothesis is that the energetic effect for corals of decreasing light with depth is offset by increasing particle and/or nutrient fluxes associated with exposure to internal waves originating along the thermocline. Alternative, and not necessarily mutually exclusive mechanisms that may contribute to the observed growth patterns include variation in zooxanthellae within and among coral colonies, water motion, and ecological interactions with other reef organisms such as fishes or benthic algae. While growth of epiphytic algae on the coral transplant holders was limited and did not directly contact the transplanted M. madracis branch tips, the portions of the reef at 20 and $10 \mathrm{~m}$ at this site supported high densities of benthic algae such as Dictyota spp. during 1999 (authors' observations). None of the $M$. mirabilis branch tips in this experiment showed marks of fish bites, but ecological interactions with coral predators certainly may have important, depth dependent effects on coral populations. Also, it is important to note that the present transplant experiment does not allow testing for possible effects related to the source of corals at $15 \mathrm{~m}$ or possible interactions between the source location and transplant depths. The logically preferable design of a complete reciprocal transplant experiment would be logistically difficult to perform in this environment because of the relative scarcity of naturally occurring $M$. mirabilis colonies at the shallowest and deepest depths (authors' observations). It seems unlikely, however, that source effects can explain the reduced growth at $20 \mathrm{~m}$ relative to the other transplant depths, as this was close to the depth of the source coral colonies and the transplanted corals exhibited higher growth rates at both 10 and $30 \mathrm{~m}$.

The comparison of growth rates from Jamaica with previous results from the Florida Keys is noteworthy for several reasons. First, observing qualitatively similar results in widely separated sites (and at different times) lends support to the proposition that biologically relevant physical processes contribute to these patterns at multiple sites. Second, the overall growth rate of Madracis mirabilis was significantly greater in Florida than in Jamaica. The observation of thermal conditions that are cooler overall and far more variable in Florida than in Jamaica warrants further investigation into the relationships between coral growth rates, temperature per se, and the upwelling of particles and nutrients associated with internal waves. Finally, the complex patterns of growth as a function of depth observed in both Jamaica and Florida highlight the potential differences between ecological processes in deep and shallow reef environments. The need to understand the loss of coral cover, the changes in reef-species distributions, and the responses of coral reefs to climate and sea-level changes is increasing rapidly (Aronson 2001). Further studies of physical and biological forcing-mechanisms across depth gradients should be extremely valuable.

Acknowledgements. We thank the people of Jamaica for their hospitality, and the staff of the Discovery Bay Marine Laboratory for technical support. The East/West Marine Biology Program provided additional support in Jamaica, and B. Agius, H. Stewart, J. Idjadi, M. Pietrak and M. Haley assisted with work in the field and laboratory. We thank P. Gayle for assistance with logistics for deep diving. Work in the Florida Keys was supported by a grant from the University of North Carolina at Wilmington and National Undersea Research Center to J.J.L. Funding to J.J.L. was also provided by National Science Foundation grant OCE-0239449. P. Edmunds, M. Vermeij, B. Helmuth, S. Wing, W. Precht, and G. Shellenbarger provided valuable discussion. The manuscript was significantly improved through comments of 2 anonymous reviewers. This is contribution 714 of the Discovery Bay Marine Laboratory.

\section{LITERATURE CITED}

Anthony KRN (1999) Coral suspension feeding on fine particulate matter. J Exp Mar Biol Ecol 232:85-106

Anthony KRN (2000) Enhanced particle-feeding capacity of corals on turbid reefs (Great Barrier Reef, Australia). Coral Reefs 19:59-67

Anthony KRN, Fabricius KE (2000) Shifting roles of heterotrophy and autotrophy in coral energetics under varying turbidity. J Exp Mar Biol Ecol 252:221-253

Anthony KRN, Hoegh-Guldberg O (2003) Variation in coral photosynthesis, respiration and growth characteristics in contrasting light microhabitats: an analogue to plants in forest gaps and understoreys? Funct Ecol 17:246-259 
Aronson RB (2001) The limits of detectability: short-term events and short-distance variation in the community structure of coral reefs. Bull Mar Sci 69:331-332

Bak RPM, Joenje M, de Jong I, Lambrechts DYM, Nieuwland G (1998) Bacterial suspension feeding by coral reef benthic organisms. Mar Ecol Prog Ser 175:285-288

Bak RPM, Nieuwland G, Meesters EH (2005) Coral reef crisis in deep and shallow reefs: 30 years of constancy and change in reefs of Curacao and Bonaire. Coral Reefs 24:475-479

Barnes DJ, Chalker BE (1990) Calcification and photosynthesis in reef-building corals and algae. Ecosyst World 25:109-131

Bruno JF, Edmunds PJ (1997) Clonal variation for phenotypic plasticity in the coral Madracis mirabilis. Ecology 78 : $2177-2190$

Bruno JF, Edmunds PJ (1998) Metabolic consequences of phenotypic plasticity in the coral Madracis mirabilis (Duchassaing and Michelotti): the effect of morphology and water flow on aggregate respiration. J Exp Mar Biol Ecol 229:187-195

Cacchione DA, Drake DE (1986) Nepheloid layers and internal waves over continental shelves and slopes. Geo-Mar Lett 6:147-152

Coles SL, Fadlallah UH (1991) Reef coral survival and mortality at low temperatures in the Arabian Gulf: new speciesspecific lower temperature limits. Coral Reefs 9:231-237

Day RW, Quinn GP (1989) Comparisons of treatments after an analysis of variance. Ecol Monogr 59:433-463

Done TJ (1983) Coral zonation: Its nature and significance. In: Barnes DJ (ed) Perspectives on Coral Reefs. B. Clouston, Manuka, ACT, p 107-147

Falkowski PG, Jokiel PL, Kenzie RAI (1990) Irradiance and corals. Ecosyst World 25:89-107

Ferrier-Pages C, Allemand D, Gattuso JP, Jaubert J, Rassoulzadegan R (1998) Microheterotrophy in the zooxanthellate coral Stylophora pistillata: effects of light and ciliate density. Limnol Oceanogr 43:1639-1648

Goreau TF (1959) The ecology of Jamaican Coral Reefs. 1. Species composition and zonation. Ecology 40:67-90

Hoegh-Guldberg O, Smith GJ (1989) The effect of sudden changes in temperature, light and salinity on the population density and export of zooxanthellae from the reef corals Stylophora pistillata Esper and Seriatopora hystrix Dana. J Exp Mar Biol Ecol 129:279-303

Hughes TP, Jackson JBC (1985) Population-dynamics and life histories of foliaceous corals. Ecol Monogr 55:141-166

Jerlov NG (1966) Optical oceanography. Elsevier Science, Amsterdam

Johnson DR, Weidemann A, Pegau WS (2001) Internal tidal bores and bottom nepheloid layers. Cont Shelf Res 21: 1473-1484

Jokiel PL (1978) Effects of water motion on reef corals. J Exp Mar Biol Ecol 35:87-97

Jokiel PL, Coles SL (1990) Response of Hawaiian and other Indo-Pacific reef corals to elevated temperature. Coral Reefs 8:155-162

Kleypas JA, Buddemeier RW, Archer D, Gattuso JP, Langdon C, Opdyke BN (1999) Geochemical consequences of increased atmospheric carbon dioxide on coral reefs. Science 284:118-120

Lang JC (1973) Interspecific aggression by scleractinian corals. II. Why the race is not only to the swift. Bull Mar Sci 23:260-279

Editorial responsibility: Otto Kinne (Editor-in-Chief), Oldendorf/Luhe, Germany
Leichter JJ, Wing SR, Miller SL, Denny MW (1996) Pulsed delivery of subthermocline water to Conch Reef (Florida Keys) by internal tidal bores. Limnol Oceanogr 41:1490-1501

Leichter JJ, Shellenbarger G, Genovese SJ, Wing SR (1998) Breaking internal waves on a Florida (USA) coral reef: a plankton pump at work? Mar Ecol Prog Ser 166:83-97

Leichter JJ, Stewart HL, Miller SL (2003) Episodic nutrient transport to Florida coral reefs. Limnol Oceanogr 48: 1394-1407

Leichter JJ, Deane GB, Stokes MD (2005) Spatial and temporal variability of internal wave forcing on a coral reef. J Phys Oceanogr 35:1945-1962

Mann KH, Lazier JRN (1996) Dynamics of marine ecosystems: biological-physical interactions in the oceans. Blackwell Science, Cambridge, MA

Massel SR, Done TJ (1993) Effects of cyclone waves on massive coral assemblages on the Great Barrier Reef: meteorology, hydrodynamics and demography. Coral Reefs 12: 153-166

Porter JW (1974) Zooplankton feeding by the Caribbean reefbuilding coral Montastrea cavernosa. Proc 2nd Int Coral Reef Symp 1:111-125

Sebens KP, Vandersall KS, Savina LA, Graham KR (1996) Zooplankton capture by two scleractinian corals, Madracis mirabilis and Montastrea cavernosa, in a field enclosure. Mar Biol 127:303-317

Sebens KP, Witting J, Helmuth B (1997) Effects of water flow and branch spacing on particle capture by the reef coral Madracis mirabilis (Duchassaing and Michelotti). J Exp Mar Biol Ecol 211:1-28

Sebens KP, Grace SP, Helmuth B, Maney EJ, Miles JS (1998) Water flow and prey capture by three scleractinian corals, Madracis mirabilis, Montastrea cavernosa and Porites porites, in a field enclosure. Mar Biol 131:347-360

Stafford-Smith MG, Ormond RFG (1992) Sediment-rejection mechanisms of 42 species of Australian scleractinian corals. Aust J Mar Freshw Res 43:683-705

Underwood AJ (1997) Experiments in ecology: their logical design and interpretation using analysis of variance. Cambridge University Press, New York

Vermeij MJA, Bak RP (2002) How are coral populations structured by light? Marine light regimes and the distribution of Madracis. Mar Ecol Prog Ser 233:105-116

Vermeij MJA, Bak RPM (2003) Species-specific population structure of closely related coral morphospecies along a depth gradient (5-60 m) over a Caribbean reef slope. Bull Mar Sci 73:725-744

Vermeij MJA, Sampayo E, Broker K, Bak RPM (2004) The reproductive biology of closely related coral species: gametogenesis in Madracis from the southern Caribbean. Coral Reefs 23:206-214

Veron JEN (1995) Corals in space and time: the biogeography and evolution of the Scleractinia. Comstock/Cornell, Ithaca, NY

Wolanski E (1994) Physical oceanographic processes of the Great Barrier Reef. CRC, Boca Raton, FL

Wolanski E, Pickard GL (1983) Upwelling by internal tides and kelvin waves at the continental shelf break on the Great Barrier Reef. Aust J Mar Freshw Res 34:65-80

Yentsch CS, Yentsch CM, Cullen JJ, Lapointe B, Phinney DA, Yentsch SW (2002) Sunlight and water transparency: cornerstones in coral research. J Exp Mar Biol Ecol 268:171-183

Yonge CM (1940) The biology of reef-building corals. Sci Rep Gt Barrier Reef Exped 1:353-389

Submitted: July 15, 2005; Accepted: November 3, 2005

Proofs received from author(s): June 2, 2006 